\title{
THEORY TO PRACTICE: A TYPOLOGY OF SUPPLY CHAIN MANAGEMENT IN CONSTRUCTION
}

\author{
Stuart Tennant \\ Department of Civil Engineering, University of the West of Scotland, Paisley, UK, PA1 $2 B E$.
}

\section{Scott Fernie}

Department of Civil Engineering \& Building, Loughborough University, Loughborough, UK, LE11 $3 T U$

\begin{abstract}
Supply chain management in construction continues to attract considerable academic and industry interest. With its origin in manufacturing, successful implementation of supply chain management is argued to enhance customer value whilst simultaneously reducing business costs. In the UK construction industry, supply chain management strategies remain largely synonymous with best practice initiatives such as construction partnering, strategic alliances and more recently construction framework agreements. In contrast to this arguably misleading and impoverished viewpoint, the purpose of this research is to develop fresh perspectives and present a contextually sympathetic typology of supply chain management in construction. Drawing on new organizational institutionalism, economic governance and transactional cost economics (TCE), the utility and performance of supply chain management in construction is portrayed as rational choice among multiple strategies, instrumentally bound by contract and context. This contextually sensitive interpretation of supply chain management captures complex, diverse and often unique characteristics of construction practice. Challenging mainstream assessment of supply chain management can clearly help construction stakeholders focus attention on discrete supply chain strategies that best suit their organizational and project needs.
\end{abstract}

Keywords: Supply Chain Management, Economic Organization, Typology, Construction. 


\section{INTRODUCTION}

The purpose of this paper is to encourage and develop fresh perspectives of supply chain management in construction. The theory and practice of supply chain management continues to attract considerable academic and industry attention (Pryke, 2009, O'Brien et al., 2009, Benton and McHenry, 2010). Successful supply chain management strategies are thought to significantly improve customer value whilst simultaneously reducing business costs (Omar et al., 2012). However, effective supply chain management strategies have become largely synonymous with collaborative forms of working (Fawcett and Magnan, 2002).

In construction, the uptake of supply chain management is routinely linked with best practice initiatives such as construction partnering (Green et al., 2005, Gruneberg and Hughes, 2004), strategic alliances (Meng et al., 2011) and more recently construction framework agreements (Tennant and Fernie, 2012). Despite growing industry awareness, the performance of supply chain management in construction is still widely perceived to lag behind other sectors, most notably manufacturing (Harty, 2008, Bankvall et al., 2010, Segerstedt and Olofsson, 2010). To describe construction as a laggard is arguably crude and ill-advised. Vindication for the success of supply chain management in manufacturing will ultimately come from a procedural analysis and exploration of the commercial relations that are embedded in those practices. Construction practice is manifestly different (Groak, 1994, Howell, 1999, Fernandez-Solis, 2008).

Despite patent differences, supply chain management practices adopted elsewhere continue to be drawn upon and used by policy makers as instrumental to achieving improved efficiencies within the UK construction industry (Egan, 1998). Such industry comparisons however, mask an inherent problem in treating the enactment of supply chain management as acontextual (Fernie and Thorpe, 2007, Green et al., 2010). These impoverished industry comparisons 
consistently fail to scrutinize fundamental theories that underpin the utility and performance of supply chain management in specific contexts.

Indeed, supply chain management is associated with an enormous body of literature that draws upon robust, reliable and fundamental economic and organizational theories. Very few academics, policy makers and industry practitioners draw upon such theories to interrogate and inform supply chain management theory and practice. This is a significant oversight in the development and diffusion of theories to fully explain the uptake, adaptation and on occasion, non-adoption of supply chain management in construction (Fernie and Tennant, 2013). The construction industry arguably requires greater engagement with established theories that help articulate the utility, complexity, connectivity and diversity of construction exchange relationships (London and Kenley, 2001, Vrijhoef and London, 2009). In short, supply chain management in construction needs more robust theoretical foundations and fewer simplistic industry comparisons.

This paper contributes to the discourse by drawing upon theoretical explanations of economic organization that underpin and inform supply chain management strategies (Williamson, 2008). In doing so, connection to the context of construction can be developed to help explain the utility and performance of supply chain management in construction. The paper is guided by the principles of narrative synthesis (Popay et al., 2006). The selection of narrative synthesis is largely dictated by the nature of the research ambition; to develop conceptual schemata, propositions and typologies. The chosen research methodology is not designed to test a theory. On the contrary, the idea is to systematically compare and contrast established theory with practice, iterating towards a contextually sensitive supposition that better reflects the practice under scrutiny; namely, supply chain management in construction.

Narrative synthesis is not without criticism. Various sections of the research community advise that narrative synthesis may deviate beyond acknowledged tenets of research 
orthodoxy; namely, validity, reliability and objectivity (Polkinghorne, 2007, Denyer et al., 2008). Despite its growing popularity, this approach to systematic review and conceptual theory development arguably lacks robust safeguards against potential research bias (Rodgers et al., 2009).

Nonetheless, seeking solace in the three precepts recommended by Solow (2001 p.111), "keep it simple; get it right; make it plausible," and remaining mindful of the limitations and assumptions ought to preserve the integrity of the methodology adopted. Carefully constructing a research narrative that is grounded (Green et al., 2010), practical (Lewin, 1943), plausible (Weick, 1989, Solow, 2001) and interesting (Davis, 1971) will undoubtedly help bridge the gap between extant theory, public policy (Popay et al., 2006) and industry performance. It is in this area that the paper hopes to make a useful contribution - to present a fresh and contextually sympathetic typology of supply chain management in construction.

The paper is arranged in a format reflective of narrative synthesis; namely, theory, synthesis, exploration and evaluation (Popay et al., 2006). The first part of the paper provides a methodical framework that draws upon a fundamental understanding of supply chain management and theories of economic organization. These theories provide the instrument with which to interrogate supply chain management in construction. The second part provides a synthesis of this framework with an understanding of exchange relationships in construction. What is presented is a stylized and contextually sensitive typology of supply chain management in construction. The third part provides a more detailed discussion and exploration of the typology and how this relates to the wider debates. The paper concludes with a summary of key points and a clear recommendation for theory-driven empirical research. 


\section{SUPPLY CHAIN MANAGEMENT: A DEFINITION}

Notwithstanding the growing popularity of supply chain management (O'Brien et al., 2009), a universal definition remains elusive (Tan, 2001, Maqsood et al., 2007). It is frequently easier to gain agreement about what supply chain management is not than lament about what supply chain management is (Stock and Boyer, 2009, Skitmore and Smyth, 2009). The lack of exactness represents a dilemma for supply chain enthusiasts. Too precise a definition may exclude valid avenues of interest, too vague and it may become another fashion label in contemporary management rhetoric (New, 1997).

Whilst some continue to advocate a consensus definition (Stock and Boyer, 2009), there is little empirical evidence to suggest that a homogeneous supply chain management strategy is a sagacious standpoint (Vanpoucke et al., 2009, Hopkins, 2010). On the contrary, diverse organizations under evolving and dynamic trading conditions will in all-likelihood adopt alternative procurement, purchasing and logistical strategies to appropriate best value from the supply chain. Acknowledging the lack of clarity in meaning and execution, supply chain management may be better explored as a malleable modus operandi.

Despite the prevailing discord and ambiguity, careful navigation of the definition thicket discloses two key milestones in the maturation of supply chain management; namely, a functional school of thought and a philosophical school of thought. The functional school of supply chain management, with its origins in manufacturing, places considerable emphasize on logistics, purchasing and operations (Saad et al., 2002, Maqsood et al., 2007, Croom et al., 2000). According to Spekman et al (1998) and Cox et al (2006) the 'function’ of supply chain management is to purchase and distribute goods and services at the lowest transactional cost whilst simultaneously securing supply. 
In the 1980’s, new and progressively global markets (Miles and Snow, 1986) began to inspire innovative and increasingly abstract interpretations of supply chain management (Cooper and Ellram, 1993). In response to globalization, supply chain management thinking evolved from a functional outlook to an all-embracing business philosophy (Skitmore and Smyth, 2009). Corporate endorsement of a ‘supply chain orientation’ (Omar et al., 2012) or supply chain management as a 'way of working' (Ellram and Cooper, 1990), traverses many management themes (Vrijhoef and Koskela, 1999) organizational functions (CSCMP, 2009) and industry boundaries.

Recent calls from the supply chain management community have arguably established a third distinctive milestone in the maturation process; namely, a conceptual school of thought (Carter, 2011, Choi and Wacker, 2011). Conceptual theory development arguably defines a scientific discipline (Carter, 2011), provides operational legitimacy (Pinder and Bourgeois, 1982) and formulates robust systematic frameworks (Whetten, 1989) for subject analysis, diffusion and evaluation. To confront established tenets of supply chain management with an introspective and critical appraisal is arguably a symbol of growing maturity and a reflection of an increasingly progressive scientific outlook. Theory development in the built environment has also received recent attention (Koskela, 2008). Despite interest in conceptual development, connecting theory building with supply chain management and the construction industry arguably remains underdeveloped, marginalized, patchy and without significant sponsorship.

\section{Supply Chain Management and Construction}

Over the past two decades, the construction industry has sought to 'borrow' management initiatives from other industries (Egan, 1998, Briscoe and Dainty, 2005), including supply chain management (Holti et al., 2000). In theory, the construction sector represents a near perfect model for supply chain management protocol (DECC, 2011). The construction 
industry is highly dependent on an extensive web of specialist and general suppliers and subcontractors (Rezgui and Miles, 2010). As a result, the commercial exchange of goods and services in a construction project typically account for approximately $75 \%$ - $90 \%$ of the total project construction cost (Holti et al., 1999, Dubois and Gadde, 2000, Hartmann and Caerteling, 2010).

In practice, the uptake of supply chain management in construction has been at best, circumspect (Love et al., 2004, Wolstenholme, 2009). Many “enduring impediments” (Briscoe and Dainty, 2005 p.324) have discouraged supply chain adoption (Fernie and Tennant, 2013). In stark difference to the unilateral, long-term trading relations symbolic of the manufacturing sector, the construction industry is multiparty (Rezgui and Miles, 2010), short-termist (Dubois and Gadde, 2000) and has a reputation for low-trust, adversarial trading relations (Korczynski, 1996, Akintoye et al., 2000).

According to Green et al (2005) and Cox and Ireland (2002), the apparent lack of supply chain success is not necessarily a failure of either supply chain management or construction. The lack of success is a consequence of insufficient attention being paid to the contextual circumstances of a complex, diverse and project driven construction environment (Hughes, 2009, Green, 2011). Hence, 'borrowing' management ideas embedded in alternative industry experiences and rooted in alien economic and cultural settings (Ho et al., 2009) requires carefully crafted and contextually sensitive solutions (Kumaraswamy et al., 2008, Harty, 2008).

\section{BUILDING ON A FOUNDATION OF ORGANIZATIONAL THEORY}

Organizational theory has a distinguished history and encompasses the disciplined study and careful application of knowledge about how people act within and around organizations (Scott, 2008). The guiding principles of organizational theory and in particular mechanisms of 
economic organization (see Williamson, 1996, Powell, 1990, Ouchi, 1980, Adler, 2001) provide a coherent, robust and authoritative foundation for developing supply chain management understanding (see Williamson, 2008) in a construction context.

Following the seminal work of Coase (1937), Williamson (1975) explored in detail the relationship between organizational theory and economic exchange to develop the concept of Transactional Cost Economics (TCE). Originally, pro-market conditions (buy) were thought to offer the most economically cost efficient mechanism for commercial exchange (Williamson, 1975). Converse to pro-market principles and under certain economic conditions, it was further reasoned that hierarchical organizations (make) could also engage in commercial exchange at a lower transactional cost than the market could support (Ouchi, 1980).

The pro-market approach to organizational governance relies on competition and is regulated by the price mechanism (Adler, 2001). Under pro-market conditions, it is contested that relationship theory and social structure play only a fractional drag in the economic exchange of goods and services (Hirschman, 1970, Granovetter, 1985, Biggart and Castanias, 2001). Consequently, the decision to 'buy' from market is largely based on purchasing situations where commercial exchange is uncomplicated and asset specificity is typically very low (Gruneberg and Ive, 2000).

In contrast to pro-market forces, a hierarchical mode of organizational governance relies on bureaucracy and is regulated by authority (Adler, 2001). Organizational hierarchies display an inherent capability to monitor and control company performance (Williamson, 1975). The rationale of TCE asserts that substantial levels of specialized investment are difficult to support via a pro-market mode of governance (Zenger and Hesterly, 1997). Consequently, the decision to 'make' as opposed to 'buy' from the market is typically reserved for trading that discloses conditions of scarcity and high asset specificity. 
The market or hierarchy dichotomy failed to account for organizational relationships where trading parties incurred higher transactional costs and yet elected not to vertically integrate (Vrijhoef and London, 2009). To counter the duality of market or hierarchy, alternative explanations suggest that the 'middle ground' is populated by hybrid mechanisms of economic organization, neither market nor hierarchy (Powell, 1990, Ouchi, 1980, Adler, 2001). According to business commentators, companies frequently blur their traditional organizational boundaries by entering in to a ‘network’(Powell, 1990) or ‘clan’ (Ouchi, 1980) form of working practice. A point later conceded by Williamson (1985).

Nowadays, the concept of an inter-organizational network linking numerous buyers and suppliers is widely accepted. With a capacity to respond quickly (Powell, 1990), the network is a highly flexible and structurally agile form of organizational governance (Miles and Snow, 1986). Similarly, the notion of a clan is also firmly established within organizational theory (Chan, 1997). According to Ouchi (1980 p.135) the clan is the obverse of pro-market economic exchange since it achieves efficiency under opposite trading conditions; namely, "high performance ambiguity and low opportunism". In many ways a clan form of organization will echo networks in their hybrid classification but clans are readily distinguishable by their highly socialized trading, long-term relationships and strength of commercial solidarity (Wilkins and Ouchi, 1983).

\section{A TYPOLOGY OF SUPPLY CHAIN MANAGEMENT IN}

\section{CONSTRUCTION}

A “helicopter view” (Vrijhoef and London, 2009 p.10-10) best describes the research perspective adopted for this theory to practice exploration of supply chain management in construction. Drawing extensively on the traditions of economic organization, there is a compelling case for assimilation with supply chain management (see Williamson, 2008). The 
organizational typology of market, hybrid and hierarchy provide a coherent, robust and authoritative foundation for exploring the 'theory to practice' of supply chain management grounded in a construction setting. It may also be postulated that each mode of governance (market, hybrid and hierarchy), under certain economic, social and cultural conditions and in compliance with the guiding principle of TCE, presents the most economically advantageous transactional outcome.

Meaningful translation and detailed explanation of economic theory, organizations and supply chain management also requires expert knowledge and understanding of construction practice. The construction industry has arguably many discerning characteristics, each characteristic contributing to a unique, dynamic, diverse and highly complex commercial environment. To assist with the selection of key industry characteristics congruent with supply chain management and symbolic of construction practice, three broad classifications are used; namely contract, context and strategy. Each classification; contract, context and strategy has four inter-related characteristics (see table 1.).

Insert Table 1.

The first classification contract refers to both the legal and social working arrangement typical of construction activity in the UK. Key characteristics include (1) construction procurement, (2) legal contract, (3) social structure and (4) working culture. These characteristics align closely with a 'fit for purpose' critique of project-based contractual relations in a construction environment (Cox and Thompson, 1997, Thompson et al., 1998, Cox and Ireland, 2002) . The second classification context draws on distinct project features that arguably differentiate construction activity from industry practices adopted elsewhere, most notably the automotive 
sector, retail sector and aerospace sector. Key characteristics include (5) project timescales (Briscoe and Dainty, 2005), (6) work stream (Morledge et al., 2009), (7) technology (Tennant et al., 2012) and (8) supply chain learning (Green et al., 2005, Maqsood et al., 2007). Individually and collectively, these four characteristics help to make sense of the inimitable ‘production’ challenges facing supply chain management in construction.

The third classification strategy augments both contract and context with four basic economic dimensions that may impact on the wider commercial interests of the construction stakeholder at both an organizational and project level. Key characteristics include (9) supply competition, (10) market climate, (11) managerial intent and (12) asset specificity. Given the industry's long-standing emphasis on a transactional model of economic exchange (Dubois and Gadde, 2000, London and Kenley, 2001), these four characteristics; supply competition, market climate, managerial intent and asset specificity retain a commercial currency in the supply and demand of construction services and goods. It should be noted that the industry characteristics identified are neither definitive nor exhaustive, nor are they necessarily mutually exclusive. The twelve characteristics indentified are however emblematic of construction activity in the UK.

Drawing further inspiration from Powell’s (1990) 'Markets, Hierarchies, and Networks', a 'stylized' typology of supply chain management in construction has been developed (see Table 2). The table presents a confluence of well-established disciplines in organizational theory with contextual characteristics of the construction industry. It is conceded that supply chain management in construction is unlikely to generate 'neat' configurations as represented in Table 2. However, the typology of supply chain management in construction is innovative, pragmatic and challenges mainstream perceptions of adoption. 
Insert Table 2.

\section{DISCUSSION}

The discussion section draws upon multiple theories of economic organization to present a typology of supply chain management in construction. The discussion connects three widely recognized forms of economic organization (see Williamson, 2008); namely, open organizations, hybrid organizations and closed organizations with the diversity and complexity of economic exchange in construction. First, an open pro-market supply chain management approach is driven by supply chain competition and principally governed by the price mechanism. Second, hybrid modes of supply chain management temper the price mechanism with trust and supplant competitive trading relations with collaborative forms of working practice. Third, a closed corporate hierarchy substitute market trading across discrete organizational boundaries for a vertically integrated, in-house organizational supply chain management approach. Under these trading conditions, authority replaces price and trust and bureaucracy supplants competition and collaboration.

The typology of supply chain management in construction does not provide absolute possibilities, advantages and disadvantages for practitioners. In any construction project there are multiple parties (Rezgui and Miles, 2010) and individual stakeholders, each with an agenda (Morledge et al., 2009). Rather, the typology of supply chain management in construction provides a systematic framework with which to explore dynamic exchange relationships, commercial tensions and strategic options.

\section{Supply Chain Management in Construction: Markets}

Supply chain management driven by pro-market forces is arguably the most popular form of commercial exchange in construction. The efficiency of the pro-market exchange is achieved 
under the following trading conditions; low performance ambiguity (lowest-cost) and high opportunism (low-trust). Overlooking the commercial limitations and impoverished behavioral assumptions frequently associated with pro-market exchange mechanisms and asocial, arm's length trading, this approach to supply chain management is widely believed to work well for the construction client (OFT, 2001). Supply chain management in construction, largely governed by pro-market forces is synonymous with traditional forms of construction procurement and the Joint Contracts Tribunal (JCT) suite of contracts.

Notwithstanding the widespread popularity of JCT forms of contract (RICS, 2006, RICS, 2010), traditional procurement in the UK construction industry is routinely censured as adversarial, fragmented and dysfunctional (Latham, 1994, Holti et al., 1999, Egan, 1998, Love et al., 2002). However, to suggest that construction eschews the practice of pro-market supply chain management in favor of alternative forms of governance, such as construction partnering, strategic alliances and construction framework agreements, are simplistic and arguably misinformed. Pro-market supply chain management with its myopic focus (Cox and Ireland, 2002) and steadfast emphasis on win-lose scenarios (Cox, 2004) is very apt for the majority of construction projects.

The proclaimed shortcomings of traditional construction procurement, such as short-termism, adversarial relations and opportunistic behavior are frequently denounced by the UK Government as wasteful and counter-productive (Latham, 1994, Egan, 1998, BIS, 2013). However, the negative protestations levied at pro-market contracting are disingenuous. On the contrary, the practice of traditional construction procurement and by extension pro-market governance of the supply chain is not devoid of significant operational benefits. The dynamic and highly responsive character of competitive tendering in construction generates significant business opportunities that can readily capitalize on real-time market conditions. 
Despite their adopted role as 'official' flag bearer of supply chain management 'best practice', the UK Government readily forgoes its own ideals to exploit real-time market conditions in an opportunistic pursuit of 'more for less'(Knutt, 2010). For example, the recent economic correction motivated the UK Government to leverage and renegotiate substantial cuts in predetermined construction costs (Gardiner, 2012). A trend not confined to the public sector, private sector clients are also re-examining the commercial merits of alternative modes of supply chain governance in direct response to prevailing market conditions (Wright, 2009). Regardless of the 'best practice' rhetoric and promise of 'win-win scenarios', construction clients appear to be somewhat “prisoners of their own past behavior.” (Eriksson, 2008 p.109). It may therefore be strongly argued that an entrenched economic culture of self-interest, instrumentalism and equilibrium (Tennant and Fernie, 2012) continues to regulate commercial decision making in construction.

The enduring popularity of traditional construction procurement is also fuelled by widespread awareness that working 'collaboratively’ with supply chain 'partners' may incur addition transactional costs which may be wholly unnecessary (Cousins and Lawson, 2007). With specific reference to small and medium enterprises (SME's) which account for the significant majority of construction contracting organizations (Morton, 2002), partnering with a few, select construction organizations may compromise future contracting opportunities (Briscoe and Dainty, 2005).

In stark contrast to 'pseudo' detractors in UK Government and elsewhere, for uncomplicated construction projects with limited design input, short-term commitment and minimum construction risk, supply chain management governed principally by open pro-market economic relationships makes undeniable business sense. It could also be strongly argued that the overwhelming majority of construction projects fit this supply chain management typology. For a minority of complex, high-risk and/or repeat construction projects however, 
an alternative typology of supply chain management and associated mechanism of economic organization may provide a more advantageous transactional solution.

\section{Supply Chain Management in Construction: Hybrids (Networks and Clans)}

With hybrid forms of supply chain management, it is the notion of trust as opposed to price or authority; and collaboration rather than competition or bureaucracy that regulates the exchange relationship (Adler, 2001). Over the past two decades, trust and working ‘collaboratively’ (Lau and Rowlinson, 2009, Smyth and Pryke, 2008) coupled with contemporary forms of construction procurement, such as construction partnering (Hartmann and Bresnen, 2011), strategic alliances (Rezgui and Miles, 2010), and construction framework agreements (Tennant and Fernie, 2012) have dominated the supply chain management in construction debate.

Two key factors have arguably influenced growing industry interest in collaborative (hybrid) forms of economic relationship. First, the decade from 1998 to 2008 has previously been described as the golden age for UK construction (Wolstenholme, 2009). During this period of extended and unparalleled economic prosperity, the construction sector experienced a level of commercial reciprocity and confidence in trading relations that differed radically from the conventional economic cycle of boom and bust. Ever growing confidence in the marketplace, increasingly stable relationships and genuine opportunities for repeat business created a stimulating environment for creative commercial solutions. Second, in addition to the buoyant economic climate, two UK Government sponsored reports, 'Constructing the Team' (Latham, 1994) and ‘Rethinking Construction’ (Egan, 1998) made an indelible mark on construction industry attitudes towards 'working collaboratively', regardless of their symbolic or substantive nature. 
Not wishing to detract from their widely acclaimed contribution to UK construction, working collaboratively in the construction industry is not new (Gruneberg and Hughes, 2004). Successive industry reports dating from 1944 (see Murray and Langford, 2003) have sought to persuade construction practitioners to seek alternative forms of working practice and by extension project procurement. In addition to repeated UK Government scrutiny, organizational concepts of the ‘quasifirm’ (Eccles, 1981) and 'governance’ (Reve and Levitt, 1984) have also been routinely explored. These contributions to the economic exchange of construction services and products predate both Latham (1994) and Egan (1998). Eccles (1981) and Reve and Levitt (1984) provide a progressive commentary on construction supply networks, governance structures, mechanisms of commercial exchange and working collaboratively, prior to the introduction of contemporary contractual arrangements such as the Project Partnering Contract (PPC 2000) and New Engineering Contract (NEC). Key findings disclose tacit evidence of construction 'partnerships' (Eccles, 1981). However, the commercial interplay between price and trust is highly complex and the collegiality of the exchange relationship, sophisticated. According to Eccles (1981) and more recently Hartmann and Caerteling (2010), the façade of construction 'partnerships' belie a deep-rooted competitive intensity to achieve lowest cost. Drawing upon Williamson’s (2008) three styles of mediating the contractual interface for hybrid forms of economic organization; namely, muscular, benign and credible, it may be argued that a myopic, one-sided 'muscular' approach to commercial exchange relations have routinely exemplified the traditional hybrid typology of supply chain management in construction.

Given that construction partnerships are not new, what was arguably 'atypical' for the construction industry was the prolonged period of year on year growth in output between 1998 and 2008 (Experian, 2010). In contrast to previous and familiar economic cycles of boom and bust, the 'decade of construction prosperity’ (Wolstenholme, 2009) brought about 
an unprecedented consolidation of commercial leverage and power. Motivated by the unique economic conditions, construction partnering, strategic alliances and construction framework agreements became an increasingly attractive business proposition for construction clients and large construction contractors alike.

In an effort to secure construction services and goods within an inflationary market, construction clients offered longer-term commercial relationships. With a counter desire for continuity of work stream, large construction contractors willingly participated. As a result of this organizational reconciliation of leverage and power, the traditional 'muscular' approach to managing hybrid forms of economic organization became increasingly fragile. In its place, benign and credible styles of mediating hybrid mechanisms of supply chain management (Williamson, 2008) emerged as an unconventional albeit wholly viable business proposition for the exchange of construction services and goods.

According to Williamson (2008), benign styles of mediating hybrid relations are characterized by the willingness of all parties to cooperate and work together in the resolution of unforeseen developments. As an alternative, credible styles of mediation adopt a pro-active outlook. Acknowledging the likelihood of project difficulties and the potential for future disagreement, creditable styles of managing hybrid relationships establish alternative dispute protocols and project procedures at the outset to countervail any prospect of dysfunctional behavior. Both benign and credible styles of managing supply chain relations are regularly reflected in contemporary construction procurement routes such as construction partnering (mutual respect and cooperation), strategic alliances (alternative dispute resolution) and construction framework agreements (early warning systems).

For construction partnering, strategic alliances, and construction framework agreements to remain sustainable and supplant pro-market approaches to supply chain management, continuity of work stream is crucial (Williamson, 2008). Given that construction is unable to 
support production line values (Morledge et al., 2009), there remains an enduring, inherent and chronic operational risk that hybrid forms of supply chain management will experience an irreconcilable breakdown in confidence (trust) and mutual respect (collaboration). Under deteriorating trading conditions, it may be commercially justifiable to either abandon all corporate ties and revert to pro-market mechanisms of supply chain management or alternatively contemplate reformation of the hybrid exchange relationship via company acquisition (Granovetter, 1985) and the aggregation of in-house capability and capacity.

\section{Supply Chain Management in Construction: Hierarchies}

A hierarchical form of supply chain management in construction caters for a 'make' solution. Frequently overlooked in favor of alternative modes of supply chain management, a hierarchical supply chain management structure with clear demarcation, explicit unity of command and extensive performance measurement tools (Powell, 1990) generates unique business opportunities beyond the scope of both pro-market and hybrid supply chain management strategies (Adler, 2001). In particular, supply chain hierarchies generate an organizational capacity to invest, research, develop and market core competencies that provide ready access to highly complex construction services and products (Cox, 2009). Recent developments in a construction context would include Building Information Modeling (BIM) and off-site methods of construction production.

Converse to pro-market supply chain management characteristics, asset specificity is likely to be very high. Subsidiaries of large construction conglomerates providing specialized products (for example, off-site production methods) or demonstrating a unique and expert service provision (for example, BIM) disclose an immediate economic advantage. Industry competitors would need to incorporate the full cost of specialist acquisition, complete with associated operational risks within the project tender price (Gruneberg and Ive, 2000). Although complete corporate integration of the supply chain in construction remains highly 
improbable, provisional lessons from the construction industry (see Buildoffsite, 2009) illustrate a 'make' option may, under certain design and build constraints provide the optimum supply chain management solution.

For example, a major international property developer recently claimed their central London office development was their most successful construction project to date. Fundamental to their supply chain management strategy was the employment of one large international construction conglomerate. In addition to the parent company, four in-house subsidiaries also participated on the construction project. Upon final completion and project handover, financial experts estimated that $72 \%$ of the office development based on value, was built by the parent company and its associated business holdings (Buildoffsite, 2009).

Despite displaying unique supply chain management attributes, hierarchical forms of supply chain management in construction are not immune from dysfunctional practices. There is an innate organizational and operational risk that internal economic exchange may become increasingly bureaucratic and ultimately; institutionalized. In the event of a dramatic downturn in construction output, the subsequent lack of commercial agility and organizational flexibility to respond may lead to excessive underutilization of capital assets. In answer to increasing market volatility and in search for an optimum supply chain management solution, large construction conglomerates may elect to disaggregate their hierarchical supply chain management approach and revert to an alternative typology of supply chain management; namely pro-market or hybrid.

\section{CONCLUSION}

There are compelling reasons for the implementation of supply chain management in a construction setting. However, within construction there are also unique and complex issues that require contextually sensitive solutions. Conflating supply chain management with 
collaborative practices and drawing on comparisons with the manufacturing sector are considered unhelpful. The persuasive explanations for the success of supply chain management will ultimately come from an analysis of manufacturing processes and economies that are embedded within them. Meaningful explanations cannot solely come from an attempt to apply supply chain management practice rooted in manufacturing experience to a diverse, complex and project-driven industrial environment such as construction. Such impoverished studies can only result in describing supply chain management in manufacturing as successful and supply chain management in construction as unsuccessful.

On the contrary, supply chain management in construction needs to be studied and better understood from fresh directions, grounded in economic organization. Rather than focus on binary measures of success or failure, this paper has drawn extensively upon organizational theory and industry practice to present a contextually sensitive typology of supply chain management in construction. Each typology of supply chain management has a distinctive role; each relationship has a unique economic and social characteristic and each regulatory mechanism has a transactional contribution to make in the efficient and effective procurement of construction services and goods. Presenting supply chain management in construction as rational choice among multiple strategies, instrumentally bound by contract and context is not intended to be definitive, exhaustive nor perfectly descriptive. The purpose of the narrative is to provide a robust synthesis of complementary and competing ideas in preparation for further empirical exploration and critical examination of supply chain management in construction. This paper makes two notable contributions to the supply chain management in construction debate, 1 / contextual theory development and 2/ a typology others can use. First, connecting conceptual theory development with organizational theory, supply chain management and UK construction industry practice is a nascent field of study. Markedly, this field of study is very rarely explored within the construction management community. Secondly, the research 
presents a typology of supply chain management in construction that others can draw upon, evaluate and use. Building on the concept of theory development, supply chain management in construction arguably requires a model of knowledge and understanding that better reflects dynamic project-driven characteristics. Challenging the mainstream and largely acontextual assessment of supply chain management can clearly help construction stakeholders focus attention on discrete supply chain strategies that best suit their organizational and project needs.

After more than two decades, it is surprising that there remains little clarity surrounding the theory and practice of supply chain management in construction. As such, it is timely to explore the conceptual theory development of supply chain management in construction. This would include contributions to the supply chain management debate from highly contextualized research perspectives. Extending a narrative synthesis approach to theorydriven empirical research presents significant opportunities. Seeking fresh perspectives in the theory and practice of supply chain management in construction will craft conceptual schemata, propositions, insights, typologies and ultimately legitimacy. This requires future development and diffusion of supply chain management to be firmly grounded in the realities and institutional assumptions unique to construction.

\section{ACKNOWLEDGEMENTS}

Work on this paper was supported by EPSRC grant reference EP/G048606/1

\section{REFERENCES}

ADLER, P. S. 2001. Market, Hierarchy, and Trust: The Knowledge Economy and the Future of Capitalism. Organizational Science, 12, 215 - 234. 
AKINTOYE, A., MCINTOSH, G. \& FITZGERALD, E. 2000. A survey of supply chain collaboration and management in the UK construction industry. European Journal of Purchasing \& Supply Management, 6, 159 - 168.

BANKVALL, L., BYGBALLE, L. E., DUBOIS, A. \& JAHRE, M. 2010. Interdependence in supply chains and projects in construction. Supply Chain Management: An International Journal, 15, 385 - 393.

BENTON, W. C. J. \& MCHENRY, L. F. 2010. Construction Purchasing and Supply Chain Management, London, McGraw Hill.

BIGGART, N. W. \& CASTANIAS, R. P. 2001. Collateralized Social Relations: The Social in Economic Calculation. American Journal of Economics and Sociology, 60, 471 - 500.

BIS 2013. Construction 2025 Industry Strategy: government and industry in partnership. In: BUSINESS, I. A. S. (ed.). London: Crown.

BRISCOE, G. \& DAINTY, A. 2005. Construction supply chain integration: an elusive goal? Supply Chain Management: An International Journal, 10, 319 - 326.

BUILDOFFSITE. 2009. 160 Tooley Street The most efficient commercial building in London? [Online]. London: CIRIA.

CARTER, C. R. 2011. A Call for Theory: The Maturation of the Supply Chain Management Discipline. Journal of Supply Chain Management, 47, 3 - 7.

CHAN, A. 1997. Corporate culture of a clan organization. Management Decision, 35, 94 - 99.

CHOI, T. Y. \& WACKER, J. G. 2011. Theory Building in the OM/SCM Field: Pointing to the Future by Looking at the Past. Journal of Supply Chain Management, 47, 8 - 11.

COASE, R. 1937. The Nature of the Firm. Economica, 4, 386 - 404. 
COOPER, M. C. \& ELLRAM, L. M. 1993. Characteristics of Supply Chain Management and the Implications for Purchasing and Logistics Strategy. The International Journal of Logistics Management, 4, 13 - 24.

COUSINS, P. D. \& LAWSON, B. 2007. Sourcing Strategy, Supplier Relationships and Firm Performance: An Empirical Investigation of UK Organisations. British Journal of Management, 18, 123 - 137.

COX, A. 2004. The art of the possible: relationship management in power regimes and supply chains. Supply Chain Management: An International Journal, 9, 346 - 356.

COX, A. 2009. Strategic Management of Construction Procurement. In: O'BRIEN, W., J., FORMOSO, C., T., VRIJHOEF, R. \& LONDON, K. (eds.) Construction Supply Chain Management Handbook. London: Taylor and Francis Group.

COX, A. \& IRELAND, P. 2002. Managing construction supply chains: the common sense approach. Engineering, Construction and Architectural Management, 9, 409 - 418.

COX, A., IRELAND, P. \& TOWNSEND, M. 2006. Managing in Construction Supply Chains and Markets, London, Thomas Telford.

COX, A. \& THOMPSON, I. 1997. 'Fit for purpose' contractual relations: determining a theoretical framework for construction projects. European Journal of Purchasing \& Supply Management, 3, 127 - 135.

CROOM, S., ROMANO, P. \& GIANNAKIS, M. 2000. Supply chain management: an analytical framework for critical literature review. European Journal of Purchasing \& Supply Management, 6, 67 - 83.

CSCMP. 2009. CSCMP Supply Chain Management Definitions [Online]. Council of Supply Chain Management Professionals. Available: http://cscmp.org/aboutcscmp/definitions.asp [Accessed 08/12/2009 2009]. 
DAVIS, M. 1971. That's interesting. Philosophy of the Social Sciences, 1, 309 - 344.

DECC 2011. Energy Consumption in the UK: 2011. In: CHANGE, D. F. E. A. C. (ed.). London: DECC.

DENYER, D., TRANFIELD, D. \& AKEN, J. E. V. 2008. Developing Design Propositions through Research Synthesis. Organization Studies, 29, 393 - 413.

DUBOIS, A. \& GADDE, L.-E. 2000. Supply strategy and network effects - purchasing behaviour in the construction industry. European Journal of Purchasing \& Supply Management, 6, 207 - 215.

ECCLES, R. G. 1981. The Quasifirm in the Construction Industry. Journal of Economic Behavior and Organization, 2, 335 - 357.

EGAN, J. 1998. Rethinking Construction. DETR.

ELLRAM, L. M. \& COOPER, M. C. 1990. Supply Chain Management, Partnership and the Shipper - Third Party Relationships. The International Journal of Logistics Management, 1, 1 $-10$.

ERIKSSON, P. E. 2008. Procurement Effects on Coopetition in Client-Contractor Relationships. Journal of Construction Engineering and Management, 103 - 111. EXPERIAN 2010. Construction Forecasts: Construction forecasting and research. Summer 2010. London.

FAWCETT, S. E. \& MAGNAN, G. M. 2002. The rhetoric and reality of supply chain integration. International Journal of Physical Distribution \& Logistics Management, 32, 339 361.

FERNANDEZ-SOLIS, J. 2008. The systemic nature of the construction industry. Architectural Engineering and Design Management, 4, 31 - 46. 
FERNIE, S. \& TENNANT, S. 2013. The non-adoption of supply chain management. Construction Management and Economics.

FERNIE, S. \& THORPE, A. 2007. Exploring change in construction: supply chain management. Engineering, Construction and Architectural Management, 14, 319 - 333.

GARDINER, J. 2012. Building By Numbers. Building Magazine. Building.

GRANOVETTER, M. 1985. Economic Action and Social Structure: The Problem of Embeddedness. American Journal of Sociology, 91, 481 - 510.

GREEN, S. 2011. Making Sense of Construction Improvement, Oxford, Wiley-Blackwell.

GREEN, S., FERNIE, S. \& WELLER, S. 2005. Making sense of supply chain management: a comparative study of aerospace and construction. Construction Management and Economics, 23, $579-593$.

GREEN, S., KAO, C.-C. \& LARSEN, G. D. 2010. Contextualist Research:Iterating between Methods While Following an Empirically Grounded Approach. ASCE Journal of Construction Engineering and Management, 136, 117 - 126.

GROAK, S. 1994. Is construction an industry? Notes towards a greater analytic emphasis on external linkages. Construction Management and Economics, 12, 287 - 293.

GRUNEBERG, S. \& HUGHES, W. Construction Consortia: do they serve any real purpose? In: KHOSROWSHAHI, F., ed. 20th Annual ARCOM Conference, 2004 Edinburgh. ARCOM, 343 - 352.

GRUNEBERG, S. \& IVE, G. 2000. The Economics of the Modern Construction Firm, London, MacMillan Press.

HARTMANN, A. \& BRESNEN, M. 2011. The emergence of partnering in construction practice: an activity theory perspective. Engineering Project Organization Journal, 1, 41 - 52. 
HARTMANN, A. \& CAERTELING, J. 2010. Subcontractor procurement in construction: the interplay of price and trust. Supply Chain Management: An International Journal, 15, 354 362.

HARTY, C. 2008. Implementing innovation in construction: contexts, relative boundedness and actor-network theory. Construction Management and Economics, 26, 1029 - 1041. HIRSCHMAN, A. O. 1970. Exit, Voice and Loyalty: Responses to decline in firms, organisations, and states, MA, Harvard College.

HO, P. S., LIN, Y.-H., CHU, W. \& WU, H.-L. 2009. Model for Organizational Governance Structure Choices in Construction Joint Ventures. Journal of Construction Engineering and Management, 135, 518 - 530.

HOLTI, R., NICOLINI, D. \& SMALLEY, M. 1999. "Building Down Barriers" Prime Contractor Handbook of Supply Chain Management: Sections 1 \& 2. In: BERR (ed.). London: CIRIA.

HOLTI, R., NICOLINI, D. \& SMALLEY, M. 2000. The Handbook of Supply Chain Management, London, CIRIA / The Tavistock Institute

HOPKINS, M., S. 2010. The 6 Forces Driving Supply Chain Design. MITSloan Management Review. MIT Sloan Management Review

HOWELL, G. A. 1999. What is lean construction. In: TOMMELEIN, I. D. (ed.) Seventh Conference of the International Group for Lean Construction. University Of California, Berkeley, California, USA: The Lean Construction Institute.

HUGHES, W. 2009. Commentary. In: O'BRIEN, W., J., FORMOSO, C., T., VRIJHOEF, R. \& LONDON, K. A. (eds.) Construction Supply Chain Management Handbook. London: Taylor and Francis Group. 
KNUTT, E. 2010. More for Less. Construction Manager. CIOB.

KORCZYNSKI, M. 1996. The Low-Trust Route to Economic Development: Inter-Firm Relations in the UK Engineering Construction Industry in the 1980s and 1990s. Journal of Management Studies, 33, 787 - 808.

KOSKELA, L. 2008. Is a theory of the built environment needed? Building Research \& Information, 36, 211 - 215.

KUMARASWAMY, M. M., ANVUUR, A. \& MAHESH, G. 2008. Contractual frameworks and cooperative relationships. In: SMYTH, H. \& PRYKE, S. (eds.) Collaborative Relationships in Construction developing frameworks \& networks. Oxford: Wiley-Blackwell.

LATHAM, M. 1994. Constructing the Team, The final report of the Government / Industry review of procurement and contractual arrangements in the UK construction industry. London: HMSO.

LAU, E. \& ROWLINSON, S. 2009. Interpersonal trust and inter-firm trust in construction projects. Construction Management and Economics, 27, 539 - 554.

LEWIN, K. 1943. Psychology and the Process of Group Living. Journal of Social Psychology, 17, 113 - 131.

LONDON, K. A. \& KENLEY, R. 2001. An industrial organization economic supply chain approach for the construction industry: a review. Construction Management and Economics, 19, 777 - 788.

LOVE, P., E.D., IRANI, Z., CHENG, E. \& LI, H. 2002. A model for supporting interorganizational relations in the supply chain. Engineering, Construction and Architectural Management, 9, 2 - 15. 
LOVE, P., E.D., IRANI, Z. \& EDWARDS, D. J. 2004. A seamless supply chain management model for construction. Supply Chain Management: An International Journal, 9, 43 - 56.

MAQSOOD, T., WALKER, D. \& FINEGAN, A. 2007. Extending the "knowledge advantage": creating learning chains. The Learning Organisation, 14, 123 - 141.

MENG, X., SUN, M. \& JONES, M. 2011. Maturity Model for Supply Chain Relationships in Construction. Journal of Management in Engineering, April, 97 - 105.

MILES, R. E. \& SNOW, C. C. 1986. Organizations: New Concepts for New Forms. California Management Review, 38, 62 - 73.

MORLEDGE, R., KNIGHT, A. \& GRADA, M. 2009. The Concept and Development of Supply Chain Management in the UK Construction Industry. In: PRYKE, S. (ed.) Construction Supply Chain Management Concepts and case studies. Oxford: WileyBlackwell.

MORTON, R. 2002. Construction UK Introduction to the industry, Oxford, Blackwell Publishing.

MURRAY, M. \& LANGFORD, D. (eds.) 2003. Construction Reports 1944 - 98, Oxford: Blackwell Publishing.

NEW, S. J. 1997. The scope of supply chain management research. Supply Chain Management, 2, 15 - 22.

O'BRIEN, W. J., FORMOSO, C. T., LONDON, K. A. \& VRIJHOEF, R. 2009. Introduction. In: O'BRIEN, W. J., FROMOSO, C. T., VRIJHOEF, R. \& KERRY, L. A. (eds.) Construction Supply Chain Management Handbook. London: Taylor \& Francis Group.

OFT 2001. Annual Report 2001. London: HMSO. 
OMAR, A., DAVIS-SRAMEK, B., FUGATE, B. S. \& MENTZER, J. T. 2012. Exploring the Complex Social Processes of Organizational Change: Supply Chain Orientation From a Manager's Perspective. Journal of Business Logistics, 33, 4 - 19.

OUCHI, W. G. 1980. Market, Bureaucracies, and Clans. Administrative Science Quarterly, $25,129-141$.

PINDER, C. C. \& BOURGEOIS, W. V. 1982. Controlling tropes in administrative science. Administrative Science Quarterly, 27, 641 - 653.

POLKINGHORNE, D. E. 2007. Validity Issues in Narrative Research. Qualitative Inquiry, 13, 471 - 486.

POPAY, J., ROBERTS, H., SOWDEN, A., PETTICREW, M., ARAI, L., RODGERS, M., BRITTEN, N., ROEN, K. \& DUFFY, S. 2006. Guidance on the Conduct of Narrative Synthesis in Systematic Reviews: A product from the ESRC Methods Program [Online]. (http://www.conted.ox.ac.uk/cpd/healthsciencescourses/short_courses/qsr/NSguidanceV1JNoyes.pdf). [Accessed 22 May 2012 2012].

POWELL, W. W. 1990. Neither Market Nor Hierarchy: Network Forms Of Organization. Research in Organizational Behavior, 12, 295 - 336.

PRYKE, S. 2009. Introduction. In: PRYKE, S. (ed.) Construction Supply Chain Management Concepts and Case Studies. Oxford: Wiley-Blackwell.

REVE, T. \& LEVITT, R. 1984. Organization and governance in construction. International Journal of Project Management, 2, 17 - 25.

REZGUI, Y. \& MILES, J. 2010. Exploring the Potential of SME Alliances in the Construction Sector. ASCE Journal of Construction Engineering and Management, 558 - 567. 
RICS 2006. Contracts in Use: A survey of building contracts in use during 2004. London:

RICS.

RICS 2010. Contracts in Use: A Survey of Building Contracts in Use during 2007. London: RICS.

RODGERS, M., SOWDEN, A., PETTIGREW, M., ARAI, L., ROBERTS, H., BRITTEN, N. \& POPAY, J. 2009. Testing Methodological Guidance on the Conduct of Narrative Synthesis in Systematic Reviews

Effectiveness of Interventions to Promote Smoke Alarm Ownership and Function. Evaluation, $15,47-71$.

SAAD, M., JONES, M. \& JAMES, P. 2002. A review of the progress towards the adoption of supply chain management (SCM) relationships in construction. European Journal of Purchasing \& Supply Management, 8, 173 - 183.

SCOTT, R. W. 2008. Institutions and Organizations Ideas and Interests, London.

SEGERSTEDT, A. \& OLOFSSON, T. 2010. Supply Chains in the construction industry. Supply Chain Management: An International Journal, 15, 347 - 353.

SKITMORE, M. \& SMYTH, H. 2009. Marketing and Pricing Strategy. In: PRYKE, S. (ed.) Construction Supply Chain Management Concepts and Case Studies. Oxford: WileyBlackwell.

SMYTH, H. \& PRYKE, S. 2008. Introduction: Managing collaborative relationships and the management of projects. In: SMYTH, H. \& PRYKE, S. (eds.) Collaborative Relationships in Construction: developing frameworks and networks. Oxford: Wiley-Blackwell.

SOLOW, R. 2001. A native informant speaks. Journal of Economic Methodology, 8, 111 112. 
SPEKMAN, R. E., KAMAUFF, J. W. J. \& MYHR, N. 1998. An empirical investigation into supply chain management: A perspective on partnerships. International Journal of Physical Distribution \& Logistics Management, 28, 630 - 650.

STOCK, J. R. \& BOYER, S. L. 2009. Developing a consensus definition of supply chain management. International Journal of Physical Distribution \& Logistics Management, 39, $690-711$.

TAN, K. C. 2001. A framework of supply chain management literature. European Journal of Purchasing \& Supply Management, 7, 39 - 48.

TENNANT, S. \& FERNIE, S. 2012. The commercial currency of construction framework agreements. Building Research \& Information, 40, 209 - 220.

TENNANT, S., MCCARNEY, M. \& TONG, M. 2012. Re-engineering the Construction Supply Chain: Transferring on-site activity, off-site. In: SMITH, S. (ed.) ARCOM. Edinburgh: ARCOM.

THOMPSON, I., COX, A. \& ANDERSON, L. 1998. Contracting strategies for the project environment. European Journal of Purchasing \& Supply Management, 4, 31 - 41.

VANPOUCKE, E., BOYER, K. K. \& VEREECKE, A. 2009. Supply chain information flow strategies: an empirical taxonomy. International Journal of Operations \& Production Management, 29, 1213 - 1241.

VRIJHOEF, R. \& KOSKELA, L. 1999. Roles of supply chain management in construction. Proceedings IGLC-7, 133 - 146.

VRIJHOEF, R. \& LONDON, K. 2009. Review of Organizational Approaches to the Construction Supply Chain. In: O'BRIEN, W., J., FORMOSO, C., T., VRIJHOEF, R. \& LONDON, K., A. (eds.) Construction Supply Chain Management Handbook. London: Taylor and Francis Group. 
WEICK, K. E. 1989. Theory Construction as Disciplined Imagination. Academy of Management Review, 14, 516 - 531.

WHETTEN, D. A. 1989. What Constitutes a Theoretical Contribution? Academy of Management Review, 14, 490 - 495.

WILKINS, A. L. \& OUCHI, W. G. 1983. Efficient Cultures: Exploring the Relationship Between Culture and Organizational Performance. Administrative Science Quarterly, 28, 468 $-481$.

WILLIAMSON, O. E. 1975. Markets and Hierarchies: Analysis and Antitrust Implications, New York, The Free Press.

WILLIAMSON, O. E. 1985. The Economic Institutions of Capitalism, London, Collier Macmillan Publishers.

WILLIAMSON, O. E. 1996. The Mechanisms of Governance, Oxford, Oxford University Press.

WILLIAMSON, O. E. 2008. Outsourcing: Transaction Cost Economics and Supply Chain Management. Journal of Supply Chain Management, 44, 5 - 16.

WOLSTENHOLME, A. 2009. Never waste a good crisis: A review of Progress since Rethinking Construction and Thoughts for Our Future. London: Constructing Excellence in the Built Environment.

WRIGHT, E. 2009. 'I will not be taken for granted': BAA's boss on frameworks. Building Magazine. Building 2009.

ZENGER, T. R. \& HESTERLY, W. S. 1997. The Disaggregation of Corporations: Selective Intervention, High-powered Incentives, and Molecular Units. Organizational Science, 8, 209 222. 